\title{
Residential choices as a driving force to vertical segregation in Whitechapel Corresponding Author:
}

Dr Shlomit Flint

Centre for Advanced Spatial Analysis (CASA)

University College London (UCL)

90 Tottenham Court Road, London W1T 4TJ, UK

Email shlomit.flint@ucl.ac.uk

\begin{abstract}
This study examines the impact of habitat choices and householder migration on Inter-building Vertical segregation in Whitechapel, a diverse inner-city neighbourhood in London. For migrants living in this absorption area, the need for a sense of belonging and continuity leads to the development of micro mechanism that improve the individuals' ability to cope with the urban challenges. Based on residential records at the resolution of single families and flats that cover a period of 17 years, the study reveal and analyse powerful mechanism of residential segregation at the vertical dimension of buildings, which the dwellers are recognise, adjust to and obey. Taken together, this mechanism is a candidate for explaining the dynamics of residential segregation in Whitechapel during 1995-2012.
\end{abstract}

\section{Keywords}

Whitechapel, Vertical Segregation, Residential, London

\section{Acknowledgments}

This research was carried out under a Marie Curie Fellowship PIEF-GA-2012-328820 while based at Centre for Advanced Spatial Analysis (CASA) University College London (UCL), supervised by Prof. Michael Batty. The writing up has been supported by The Arts and Humanities Research Council (AHRC) grant Survey of London: Whitechapel Initiative, based in the Bartlett School of Architecture and CASA, University College London (R24 AH/N00146X/1). 


\section{Residential choices as a driving force to vertical segregation in Whitechapel}

Introduction: non-economic Vertical segregation - what do we know about it?

Ever since cities became large and complex, they developed cultural and urban mechanisms technological, organisational, legal, and social - to tackle their own pressing problems of demographic and economic growth (Hall, 1998). One of these age-old mechanisms, characterizing both ancient cities and current urban centres is Segregation, a well-known residential pattern which is the outcome of householder migration and habitat choices (Boal, 1978; 1996; Chivallon, 2001). Despite extensive research of the causes and patterns of 17 different forms of neighbourhood segregation - among them the rare types of segregation between the front and the back of residential buildings and overcrowding in similar buildings

- the vertical dynamics of ethno-religious enclave and the role of individuals' preferences and social relations in shaping minority groups' spaces still await deeper insight. This article, however, examines how individuals' identity and local residential preferences play a central role in everyday life and are reflected in the vertical segregation of Whitechapel neighbourhood.

White (1984) described vertical differentiation as the most widespread type of segregation, allowing people from different classes to share and interact in the same living space. This phenomenon characterises mainly compact built heterogeneous cities that developed gradually through individual-level residential decisions (White, 1984; Maloutas and Karadimitriou, 2001). A description of this mechanism, operated in eighteenth century Paris, is provided by Roche (1987) who outlines it as "inequality began in relation to space". In addition to the horizontal Segregation - the northwest quadrant of Paris was generally inhabited by the wealthy, and the northeast by the proletariat - there was also a Vertical Segregation. As people 
of different classes often lived together in the same building, there were clear advantages to being wealthy: "The lower storeys were reserved for owners, middle-class master-craftsman, shopkeepers or the principal tenants. Poorer families lived on higher floors, with many more people in each room" (Roche, 1987). Nowadays, with the exception of some slum areas and modern housing districts, the middle and working classes live together in vertically stratified apartment blocks: the working class and service labourers live in lower floors while the wealthier on top floors and in penthouses (Allum 1973; Leontidou, 1990).

Current research, however, relates vertical segregation to gentrification processes, and claims that the integration of various population groups in the same buildings solves the emerging problems caused by the city's own growth, while simultaneously preventing the formation of slums (Coing, 1966; Smith and Williams, 1986; Glass, 1989). In this process of social redistribution and re-appropriation of residential space in mature urban settings, where change no longer refers primarily to rapid urbanization but to internal reforming, changes of scale and form of segregation are often involved through the diversification of patterns and mechanisms for the social allocation of urban space. Hamnett (2004) illustrates this diversification for East London, where gentrifies gradually replaced the shrinking working class from the 1970s and created more variegated segregation patterns at the micro-scale in the place of former broad socio-spatial divisions. A gentrified area becomes less segregated, in terms of segregation indices, at least for some time, an outcome which in principle should be accounted as positive (Slater, 2006). However, since lower levels of segregation could be temporary - as a result from the loss of working class population in a working class area in crisis, the increased internal social mobility within a working class area under regeneration or even the loss of upper and middle class population in areas of filtering down - but actually lead towards more segregated 
situations, segregation indices are not unequivocally socially negative or positive, and there is a need to recognise the specific context of this social dynamic (Maloutas et al, 2012).

White (1984) makes a distinction between segregation and differentiation. For White, where economic factors are the primary drivers of vertical social separation within a building, this should be considered differentiation; where people are making a conscious choice to separate themselves from other ethnic or religious groups, this should be termed segregation. Since vertical differentiation is expected to be found in societies where class relations (but not ethnoracial differences) are the primary differentiating element in urban space, and where less discrimination and more egalitarian approaches underlie their regulation, White (1984) claims that it would be misleading to call this 'segregation', because it constitutes its antithesis. This research consensus, however, is that vertical segregation is particularly relevant for migrants living in diverse absorption areas, such as the Whitechapel neighbourhood - the case study of this research. Similar to other diverse neighbourhoods in UK and around the world, Whitechapel developed gradually, its character was influenced primarily by its central location and individual-level decision making. As the ethno-religious population groups in this study voluntary segregate themselves, the research thus refers to this phenomenon as "vertical segregation" and examines its cultural-economic characteristics. Whitechapel's residential dynamics offer an example of residential relations between population groups similar in their residential preferences, while different in their economic abilities. These circumstances are reflected in vertical residential patterns, enabling maintenance of unique cultural identity.

\section{Theoretical remarks}

Much of the geographic literature deals with segregation resulting from either inner forces encouraging people to congregate as a means to preserve the group's culture, language and 
customs (Macedo, 1995; Boal, 1996; Wahlstrom, 2005) or from external forces through the spatial exclusion of unwanted groups from the majority group's space (Lee Lee, 1977; Boal, 1978; Knox, 1982). The main factors for analysis of householders' residential behaviour - the socio-economic characteristics of the individual and the household on the one hand, and the socio-economic status of the housing and neighbourhood on the other - identified by Speare only in the mid 1970's (Kasarda, 1972, 1978; Speare, 1974; Speare, Goldstein and Frey, 1975). Further inquiry into these factors refined these variables, and now it is common to distinguish between revealed preferences, the actual individual behaviour; and stated preferences, individuals' declared attitudes (Giffinger, 1998; Iceland, 2004; Ihlanfeldt and Scafidi, 2002).

Studies of urban dynamics and residential choice explain segregation by referring solely to economic factors or by looking at a mixture of economic and non-economic factors (Borjas, 1998; Clark and Withers, 1999). Non-economic factors of segregation, such as family lifestyle, ethnic relationships or life-cycle characteristics, are usually merged with the economic factors (Johnstonet etal, 2007), and thus blurring the impact of non-economic factors.

A basic approach to non-economic segregation between householders who belong to one of two groups was offered by Sakoda and Schelling (Sakoda, 1971; Schelling, 1971, 1974). According to this approach, each householder considers the surrounding population to consist of 'friends' - householders belonging to the same group; and 'strangers' - householders belonging to other groups. Sakoda and Schelling further reduced the non-economic factors influencing the householder's decision to stay or to move to the fraction of 'friends' within the householder's neighbourhood. According to this model, householders aim at residing in a neighbourhood where the fraction of friends, F, is above a certain threshold. In the abstract versions of a model, which consider a square grid of cells, each populated by one householder 
only, a threshold value of $F$ varies lies within the interval $1 / 4-1 / 3$, depending on the other model parameters. This means that the tendency of a householder to reside within the neighbourhood where the fraction of friends is above one third eventually results in complete residential segregation. Despite the essential advance in studying Schelling model in its abstract 2D and 3D forms, examples of the real-world dynamics that can be described by the Schellinglike rules are very few (Flache, Hegselmann, 2001; Benenson, Omer, Hatna, 2002, Bruch and Mare, 2006; Fossett, 2006a, b).

Research shows that residential choices are determined by socio-cultural-economic interactions (Möbius and Rosenblat, 2002; Schnell and Benjamini, 2005) and that different levels of social organization play an important role in shaping segregated residential spaces (Knox and Pinch, 2000; Iceland, 2003; Christensen and Hogen-Esch, 2006; McNair, 2006). In this respect, ethno-religious minorities who require spatial congregation for maintaining their meaningful social contacts and lifestyle are usually tend to combine spatial and social segregation. In what follows this study considers Whitechapel's residential pattern as driven by the interactions between householders of different groups and investigates whether the tendency to reside among people of their own groups can explain non-economic vertical residential patterns there.

\section{The case study of Whitechapel}

London's East End developed gradually from medieval times, growth quickening in the extramural district in the late 16th century. In the late 17th century, Huguenot refugees inhabited a new weaving suburb in Spitalfields, followed in the 18th century by many Irish Catholics, in the late 19th century by Jews and in the late 20th by Bangladeshis (Lupton and Power, 2004). Many Jewish and Bengali immigrants worked in the clothing industry with low wages and poor 
conditions, and from around 1890 the area became associated with poverty, overcrowding, disease and criminality. Official attempts to address under-investment in housing stock through the public sector began in the 1890s under the auspices of the London County Council. World War II devastated much of the East End, leading to dispersal of the population. During the 1950s, the area reflected the structural and social changes of slum clearance and war-time destruction. New public housing was built and a high proportion of immigrants and their descendants eventually found places in council accommodation (Lee and Murie, 1997). The closure of the last of the East London docks in 1980 led to attempts at regeneration to the south and east of Whitechapel. Subsequently, with its close proximity to the financial centre of London and the strong presence of economic regeneration together with social policy activity, has led to much new development in Whitechapel (Hammett, 2003). However, despite renewal and a massive gentrification process, some parts of the East End have continued to suffer considerable social and economic disadvantage, containing some of the most deprived areas in Britain. These areas are largely populated by the UK's youngest and fastest growing minorities, who are encouraged to preserve tradition based on family ties in compact areas (Kintrea et al, 2008; Dustmann and Theodoropoulos, 2010).

Today, the large number of 61 religious institutions in the area reflects the diversity of Whitechapel's population. The area is populated by Muslims, Hindus and Christians of African, British, South-Asian, East-Asian and European origin. Each of these groups has brought its own distinctive customs and traditions to enrich the area's life and culture. The largest sub-group living in the Borough of Tower Hamlets is Bangladeshi-Muslim (30\%), representing one of the largest concentrations of Muslim ethnicity in Europe (Carey and Shukur, 1985; Dench et al, 2006; Stillwell and Duke, 2005). The other groups in the area are relatively small, divided in this research by their place of origin. 
[Place Figure 1 about here]

\section{Construction of Whitechapel's spatio-temporal population GIS}

To investigate residential relationships in the research area among Whitechapel's population groups, a detailed spatio-temporal database that contains exact geo-referenced data on family religious affiliation was constructed. The field research was conducted during 2011-12 at the level of individual families and flats. Together with a local interviewer, a young male from the Bangladeshi community (who has requested anonymity), the author conducted a door-to-door survey and interviewed 4656 Families living in 3186 Flats. As the interviewer was already familiar with the Bangladeshi civil community, and the author speaks Bengali, they were able to gather rich and sometimes controversial data by this means. The households were asked to identify themselves as well as the flat's former dwellers, going back to at least 1995. Several researchers stress that the identity of previous residents is important for traditional families (Waterman and Kosmin 1987, 1988), a conclusion confirmed by this research. Identification of past residents allowed us to understand which group's members had occupied each flat for the past 20 years. All other questions asked related to the present occupants in order to ascertain their socio-spatial behaviour.

Householders were also questioned about motives for choosing the flat, and asked to rank the relative importance of the flat's price, their neighbours' identity and institutional (e.g., Churches and schools) proximity (stated preferences). This field survey also collected data about the flat cost, the location of institutes and services that the families attend (revealed preferences), ownership versus rental of the flat, and the source of information about flats prior to buying or renting. Despite early apprehensions regarding cooperation, the response rate 
reached 83 percent. A high level of cooperation with the survey enables a comparison between stated and revealed preferences and recognizes similar preferences amongst the groups.

In order to complete the fundamental part of the research, 172 interviews had conducted with key figures such as community leaders, municipal planners and real estate agents. Interviewees were chosen on the basis that they offer a range of different types of knowledge and perspectives on their community. Among the interviewees also reside the last of the veteran inhabitants who could provide explanations and describe the processes taking place in the neighbourhood from their point of view. The cross-referenced data produce information on the population exchange and express the dynamic processes. The interviews will also assist in identification of further key contacts.

Construction of the Whitechapel GIS was based on layers updated to 2011 and provided by the ordnancesurvey.co.uk/opendatadownload/products.html. The characteristics of all the research area's flats and households were organized as GIS layers, in which every record in the table is related to the corresponding building. The layer was then included in the area's high-resolution GIS. A quality control process ensured consistency. This involved piloting, whereby the interviewer was required to carry out three pilot interviews to refine approaches and questions where necessary, and ongoing basis review, whereby the interviewer's field notes were reviewed weekly to ensure consistency across the project and that relevant data was picked up.

Whitechapel's GIS contains additional layers pertaining to topography, roads, land parcel, and buildings, the latter characterized by use and number of floors. There are 1,149 families in 47 communal buildings and 3,507 families in 1,615 privately owned flats in 241 buildings. 
Taken as a whole, the survey's spatio-temporal GIS enables evaluation of residential patterns at the resolution of flats, buildings, and neighbourhood; it thus makes investigation of the residential micro-dynamics in this limited environment empirically possible.

\section{Estimation of residential segregation}

The level of spatial segregation at the resolution of buildings was estimated with the Moran I index (Zhang and Linb, 2007) of spatial autocorrelation. The Moran I index was applied for estimating the correlation between the fraction of a given group $\mathrm{D}$ in building $\mathrm{i}$ and the fraction of $\mathrm{D}$ over the buildings $\mathrm{U}(\mathrm{i})$ that are adjacent to $\mathrm{i}$ :

$$
\frac{N \sum_{i} \sum_{j \in U(i)} w_{i j}\left(D_{i}-\bar{D}\right)\left(D_{j}-\bar{D}\right)}{\left(\sum_{i} \sum_{j \in U(i)} w_{i j}\right) \sum_{i}\left(D_{i}-\bar{D}\right)^{2}}
$$

where $\mathrm{N}$ is the number of $\bar{D}$ buildings and the average fraction of a group $\mathrm{D}$ in Whitechapel.

The influence wij of the neighbouring buildings $\mathrm{j} \square \mathrm{U}(\mathrm{i})$ on $\mathrm{i}$ is calculated as wij $=1 / \mathrm{NU}(\mathrm{i})$, where NU(i) is the number of buildings in $\mathrm{U}(\mathrm{i})$. The proximity of buildings is defined by a Voronoi partition constructed on the basis of the buildings' central points, as proposed by Benenson, Omer and Hatna (2002). According to this definition, two buildings are adjacent if the central points of their foundations are directly visible by the other (Figure 2):

[Place Figure 2 about here]

Residential segregation in Whitechapel

Whitechapel population dynamics 
Whitechapel's population grew until the 2000 s, in tandem with the East-European migration and the construction of new apartment buildings. In 1995 the area was populated mainly by people from South Asian origin, (most of them were from India and Bangladesh, with negligible Pakistani and Sri Lanka groups), and the general British population, with Bangladeshis steadily substituting the other South Asian groups (Figure 3). During the 2000's, new population groups entered the area, and nowadays we can recognize 30 sub-groups.

[Place Figure 3 about here]

\section{$\underline{\text { Stated residential preferences of Whitechapel householders }}$}

Table 1 shows that several population groups in Whitechapel share similar concerns (chisquare test, $\mathrm{p} \sim 0.5)$. Only the East-European dwellers chose the location of institutions as their main concern. Whitechapel's location close to the city centre ensures the proximity of such institutions. Contrary to economic theory, only one third of the population indicated that price was a critical issue for them. Most important rather is the fact that, despite the neighbourhood's reputation as a migrant's neighbourhood, the majority of Whitechapel dwellers reported that the identity of their immediate neighbours is their principal concern. As this stated preference appears to be in the first or second place and shared by members of all groups, the research can assume that the Schelling-like mechanism of actively distinguishing between "friends" and “others" remains relevant in Whitechapel. Apparently, most of the neighbourhoods' dwellers feel the need for at least a few "friends" in order to feel at home in their apartment building. What are the spatial consequences of the above stated preferences? Are they also expressed in the vertical dimension of Whitechapel residential pattern? The study thus turned to investigate 
the impact of these declared preferences on the revealed preferences of Whitechapel's dwellers based on the data of 1995-2012, when Whitechapel infrastructure remained almost steady yet residential patterns changed.

[Place Table 1 about here]

\section{Whitechapel residential pattern at the neighbourhood's level}

Based on the survey records, Whitechapel's residential patterns had re-constructed from 1995 until 2012 (Figure 4). In cases of strong tendency to reside in a friendly environment, Schelling's model results in complete spatial segregation. Despite the clear tendency to segregate, though, the maps in Figure 4 indicate the spatial integration of Whitechapel's residents, with members of several groups living in close proximity to each other. Quantitative estimation of the level of segregation is thus necessary. Moran I index (Figure 5), Indicates a significant level of segregation exists throughout the entire period for Bangladesh, and that they are the most highly segregated groups in Whitechapel, although the residential segregation of the other religious groups has been steadily growing over the years. In 1995 Moran's I index appears high for the South Asian groups from India, Pakistan and Sri Lanka, that start then start to decline, with most of these groups having left the area by 2004 .

[Place Figure 4 about here]

[Place Figure 5 about here]

Unlike the Schelling's model assumption, the capacity of Whitechapel's spatial units (buildings) is essentially higher than one family. Let us investigate the segregation processes in Whitechapel at the vertical level of residential buildings. 
Whitechapel Vertical segregation

Vertical segregation in the individual building level

Analysing the revealed preferences of Whitechapel's resident according to their faith (Table

2), shows that 80.5 per cent of the flats occupied by families that identify themselves as Muslims are located in the upper quarter of the building. Since people that identify themselves as Christians or have no religion demonstrated a non-segregated pattern in the bottom quarter, the Muslims' tendency to live in the upper parts of the buildings demands further inquiry.

Note that although Figure 5 shows that the African group is segregated, they live mainly in council housing, and the estimation of their group's segregation in the areas' privateownership's buildings $(0.4 \%)$ is insufficient. Therefore, the major Muslim groups living in the area are from Bangladesh, the Middle East, North Africa and United Arab Emirates origin. Table 3 shows that Bangladeshi, Middle East and the United Arab Emirates groups reveal similar residential choices to live in the upper parts of the buildings.

There are no lifts in four- to six-story buildings, nor loft storage nor concierge; morevoer, the price difference between the bottom and upper quarters is within normal levels for London. The study therefore went on to examine the average income of the groups, as stated by the residence, according to the location of the flat in the buildings (Figure 6).

[Place Table 3 about here]

[Place Figure 6 about here]

Figure 6 shows that families from various groups are also different in terms of their economic capabilities. While the stated average income of Families from United Arab Emirates living in 
Whitechapel is the highest, that of the Bangladeshi group is much lower, up to 60 per cent of the average London salary. Nevertheless, the differences between the stated average incomes of families living in the Upper quarter and the rest of the building are marginal for all the groups. This indicates that although better economic ability provides more opportunities in a free housing market, the revealed preference to live in the upper floors of Whitechapel's buildings is not necessarily related to economic status. The study thus turns to examine the segregation as an outcome of the relationships between the groups.

\section{$\underline{\text { Inter-building relationships }}$}

To estimate the relations of a group D with the members of the rest of groups, the study examined the distribution of the number of D-families $\mathrm{mD}$ in Whitechapel buildings in 2012 . Let the whole fraction of the D-families in Whitechapel be $d$. If D-families are neutral to the other groups, then the distribution of $\mathrm{mD}$ in Whitechapel's buildings with $\mathrm{n}$ flats will be binomial, $\mathrm{mD} \sim \mathrm{B}(\mathrm{d}, \mathrm{n})$. The comparison between the actual distribution of $\mathrm{mD}$ and $\mathrm{B}(\mathrm{d}, \mathrm{n})$ enables recognizing the particular group that is not neutral to the rest of the groups. To combine the results for different $n$, the study thus transform $m D$ into $\xi=(m D-n \cdot d) / v(n \cdot d \cdot(1-d))$ : if $n$ is large enough and $\mathrm{m}$ is binomial, then $\xi$ is distributed according to the normal distribution $\mathrm{N}(0$; 1) (Collani, Dräger, 2001). To compare the distribution of $\xi$ to the $\mathrm{N}(0 ; 1)$ the KolmogorovSmirnov test had employ (Corder, Foreman, 2009). Table 4 demonstrates that the families of each group, besides British, tend to segregate from the others. The fraction of buildings where the group is not found and the average fraction of the group

in the buildings where it is found, are essentially higher than should be expected in case of the binomial distribution.

[Place Table 4 about here] 
Members of each group tend to reside in flats vacated by householders of their own group, which can be considered as an expression of their stated preferences. For the group D these probabilities are calculated as DReplacing_D/DLeft, where DReplacing_D denotes the number of families of a group D that replaced the families of D during the year, and DLeft the overall number of the families of D that left during the year (Table 5).

[Place Table 5 about here]

To conclude, when averaged over the period of 17 years, East-European, Bangladeshi and other South Asian groups in Whitechapel are segregated within the buildings (Table 4) two first of them are segregated within the neighbourhoods (Figure 5). The replacement of the tenant of the same group (Table 5) is a strong candidate mechanism for supporting this segregation in time.

\section{$\underline{\text { Inter-Floor relationships }}$}

Schelling's lesson is that people prefer to enter a flat in buildings where the residence rate of their group is significantly higher than the percentage of their group in the population. But how could they know about the building's composition? And how come that families, sometimes with young children, prefer to live in the upper floors of a building without a lift? Could it be that the "identity" of a building is affected also by vertical segregation?

In this study, 141 interviews revealed that the visibility of ethnicity in the buildings affects the identity of the building and the entry of other populations into it. The interviewees mentioned mainly the mixing of public and private usages in the building level such as seating and talking outside internal doors, children's games in the stairwell, hanging laundry in common areas and 
smell of cooking "push" or "pull" them to a specific building. Apparently visibility of identity hint about the composition of the buildings. In this regard, 58 interviewees who live in the Upper quarter of buildings explain their benefits in living there. One of the interviewee is Afia (age 32) from Bangladesh who explains: "When you live upstairs your contact with the building increase. In this weather the children play mainly in the stairwell, people meet there and actually this is the living room of the building. When other of us seeking for a flat they immediately recognise that we live here and join. Having other around make the area more secure and the kids happy to have friends, don't need to go outside". Khalid (early 40s) from United Arab Emirates add: "We are all migrant here and whoever live upstairs designated the building with his (group). I live here almost two years and I learned that it is better like that when I was looking for a flat".

Another explanation for the preferences to live in the upper quarter of buildings supplied by Rimi (early 50s) from Bangladesh, who explains: "in the upper level you can attach part of the hallways to your flat and increase it, so you can live with your siblings' families". Examining of this statement about the semi-private/public space reveal that although one may expected to find about 937 Muslims families - which are $80.5 \%$ of the upper quarter of Whitechapel families - to live in the upper quarter, the data indicates that 1629 families actually lives there. Table 6 shows that level of density is varied between groups. Comparing this data with the stated average income (Figure 6), one can safely assume that it is a non-economic tendency.

[Place Table 6 about here] 
Conclusions: Local residential choices as a driving force to non-economic vertical segregation in Whitechapel

This study examines the impact of ethno-religious identity on Inter-building Vertical segregation, focusing on Whitechapel, an inner-city diverse neighbourhood in London. The literature describes the global cities of their time, Renaissance Florence between 1400 and 1450; Shakespearean London, Vienna in the 18th and 19th centuries; and Paris between 1870 and 1910, assumes that economic forces, namely, economic classes and employment status are the main driving forces of vertical differentiation (White, 1984; Hall, 1998). This study, however, providing an extraordinary opportunity to explain this phenomenon as a result of habitat choices and householder migration, and thus recognise it as Vertical segregation.

Although it was expected to find that better economic ability provides more opportunities and better chances to bridge the gap between the stated and revealed residential preferences in a free housing market, the study surprisingly indicates that the revealed preference to live in the upper floors of Whitechapel's buildings is not necessarily related to economic status. Despite different economic abilities shown by Whitechapel's dwellers stated average income and location of the flat in the buildings (Figure 6), Table 2 shows that 80.5 per cent of the flats occupied by families that identify themselves as Muslims are located in the upper quarter of the buildings. Most of this dwellers are Bangladeshi group whose stated average income is up to 0.6 per cent of the average London salary. Although this is much lower than the 1.4 per cent stated average income of United Emirates, both groups reveal similar preferences to live in the upper quarter of the buildings. The high probability to the replacement of the tenant of the same group as expose in Table 5 is a strong candidate mechanism for supporting this segregation in time. 
For migrants living in diverse absorption areas, such as the Whitechapel neighbourhood, the human need for a sense of belonging and continuity may lead to the development of micro mechanisms to improve the individuals' ability to cope with the challenges of urban life. The unique information collected via a comprehensive census, reveals powerful mechanisms that govern this segregation. Relatively high density of families per flat as shown in Table 6 together with small number of families from Middle East, North African and United Arab Emirates origin blurs this study's ability to apply Kolmogorov-Smirnov test on the vertical dimension. However, examining the distribution of Whitechapel's resident according to their faith in the vertical dimension and applying the K-S test on the inter-buildings level produces information on the vertical dynamic processes, while analysing the in-depth interviews provides a glimpse into why they might choose to live in the upper quarter of the buildings. We can see that similar to the age-old economic vertical differentiation, ethno-religious Vertical segregation allows people from different population groups to share and interact in the same living space. Unlike the vertical differentiation, as people of different classes lived together in the same building, there is no clear advantages to being wealthy.

The Whitechapel study has revealed that although the urban fabric may look as a patchwork of economic activity, class relations and cultural-ethno-racial mosaic, there is a clear inner-order, identity-based, which both current residents and newcomers recognise, adjust to and obey. Could it be that there are more other latent inner-orders operating in this area? To what extent does this mechanism affect the area as a whole? Going beyond Whitechapel - can we find noneconomic Vertical segregation elsewhere? Is this Inter-building Vertical mechanism another form of segregation, additional to the 17 already recognised by White (1984), or is it a latent micro order which could integrated with other forms? The answers to these questions demand the development and studying of a 3D Schelling-like model that accounts for the buildings of 
varying capacity and neighbourhoods of a varying shape and size. The results of this study will be presented in the next paper.

\section{Reference}

Allum, P. A. 1973: Politics and Society in Post-War Naples. Cambridge: Cambridge University Press.

Benenson I Omer I Hatna E, 2002, Entity-based modeling of urban residential dynamics - the case of Yaffo, Tel-Aviv. Environment and Planning B. 29, 491-512.

Boal, Fredrick W.(1978). Ethnic residential segregation. in Herbert, D. T. and Johnston, R. J. (eds) Social areas in cities, London, Wiley, 57-95

Boal, Fredrick W. (1996). Integration and Division: sharing and segregating in Belfast. Planning Practice and Research 11 (2), 151- 158

Borjas, George (1998), To Ghetto or Not to Ghetto: Ethnicity and Residential Segregation. NBER Working Papers 6176, National Bureau of Economic Research 44 (2), 228-253.

Bruch E E and Mare R D. 2006. Neighborhood Choice and Neighborhood Change. American Journal of Sociology 112(3) 667-709.

Carey, Sean.,Shukur, Abdus. (1985) A profile of the Bangladeshi community in East London, Journal of Ethnic and Migration Studies 12 (3) 405-417

Chivallon, Christine (2001). Religion as space for the expression of Caribbean identity in the United Kingdom, Environmental and Planning D: Society and Space, (19), 461-483.

Christensen, Terry and Hogen-Esch, Tom (2006). Local Politics A Practical Guide To Governing At The Grassroots. M E Sharpe Inc: United States.

Clark, William A. V. and Withers, Suzanne (1999). Changing Jobs and Changing Houses: Mobility Outcomes of Employment Transitions. Journal of Regional Science 39(4), 653-673. Coing H., 1966, Rénovation urbaine et changement social, Paris, Les Éditions Ouvrières 
Corder G and Foreman D 2009 Nonparametric Statistics for Non-Statisticians: A Step-by-Step Approach, Wiley, NY

Dench, Geoff., Gavron Kate., Young Michael.(2006) The New East End: Kinship, Race and Conflict, London: Profile Books

Dustmann, Christian. Theodoropoulos, Nikolaos. (2010) Ethnic minority immigrants and their children in Britain, Oxford Economic Papers, 62(2): 209-233.

Flache A. and Hegselmann R. (2001). Do Irregular Grids make a Difference? Relaxing the Spatial Regularity Assumption in Cellular Models of Social Dynamics Journal of Artificial Societies and Social Simulation 4(4): <http://www.soc.surrey.ac.uk/JASSS/4/4/6.html>.

Fossett M. A. 2006a. Ethnic Preferences, Social Distance Dynamics, and Residential Segregation: Theoretical Explorations Using Simulation Analysis. Mathematical Sociology 30(3-4) $185-273$.

Fossett M. A. 2006b. Including preference and social distance dynamics in multi-factor theories of segregation. Mathematical Sociology 30(3-4) 289-298.

Giffinger, Rudolf (1998). Segregation in Vienna: Impacts of Market Barriers and Rent Regulations. Urban Studies 35 (10), 1791-1812.

Glass R., 1989, Cliches of urban doom, Oxford, Blackwell.

Peter Hall (1998) Cities in Civilization: Culture, Technology, and Urban Order. London: Weidenfeld \& Nicolson; New York.

Hamnett, C. (2004) Economic and social change and inequality in global cities: the case of London. The Greek Review of Social Research 113A, 63-80.

Iceland, John (2004). Beyond Black and With Metropolitan Residential Segregation in Multi Ethnic America. Social Science Research 33, 248-271. Pantheon Books. 
Ihlanfeldt, Keith and Scafidi, Benjamin (2002). Black Self Segregation as a Cause of Housing Segregation: Evidence from the Multi-City Study of Urban Lnequality. Journal of Urban Economics 51, 366-390.

Johnston, Ron J, Poulsen, Michael., and Forrest, James (2007). The geography of ethnic residential segregation: a comparative study of five countries. Annals of the Association of American Geographers 97 (4), 713-738.

Kasarda, John D. (1972). The Theory of Ecological Expansion: An Empirical Test. Social Forces 51, 165.

Kasarda, John D. (1978). Urbanization, Community, and the Metropolitan Problem. David street (Eds.), Handbook of Contemporary Urban Life 27-35 San Francisco: Jossey-Bass,.

Kintrea, Keith., Bannister, Jon., Pickering, Jon., Reid, Maggie., and Suzuki, Naofumi. (2008)

Young People and Territoriality in British Cities. York: Joseph Rowntree Foundation

Knox, Paul. (1982). Urban social geography: an introduction. Longman, London.

Knox, Paul and Pinch, Steven (2000). Social Interaction in Urban Environments, Urban Social Geography 7 219-223

Lee, Trevor. R. (1977). Race and residence, Oxford University Press, Oxford. Macedo, Stephen (1995). Liberal Civic Education and Religious Fundamentalism: The Case of God John Rawls? Ethics (105), 468-96.

Lee, Peter. and Murie, Alan.(1997). Poverty, Housing Tenure and Social Exclusion, The Policy Press in association with the Joseph Rowntree Foundation, UK

Leontidou, L. (1990) The Mediterranean city in transition. Cambridge University Press, Cambridge.

Lupton, R. and Power, A. (2004) Minority Ethnic Groups in Britain, CASE Brooking Census Briefs No. 2. 
Maloutas, T. \& Karadimitriou, N. (2001) Vertical social differentiation in Athens: Alternative or complement to community segregation? International Journal of Urban and Regional Research, 25(4), 699-716.

McNair, D. (2006) Social and spatial segregation: ethno-national separation and mixing in Belfast. Unpublished PhD dissertation, School of Geography, Archaeology and Paleoecology, Queen's University, Belfast.

Mobius, Markus, and Tanya Rosenblat (2002). The Process of Ghetto Formation: Evidence from Chicago. Manuscript, Harvard University.

Maloutas, T., Arapoglou, V.P., Kandylis, G. \& Sayas, J. (2012) Social polarization and desegregation in Athens in T. Maloutas \& K. Fujita (eds) Residential Segregation in Comparative Perspective, Ashgate, Farnham, 257-283.

Roche, D. (1987).The People Of Paris: An Essay In Popular Culture In The 18th Century, University of California Press

Sakoda, James M. (1971). The checkerboard model of social interaction. Journal of Mathematical Sociology 1(1), 119-132.

Schelling, Thomas (1971). Dynamic models of segregation Journal of Mathematical Sociology 1(1), 143-186

Schelling, Thomas (1974). On the ecology of micro-motives In: R. Marris (Ed.) The Corporate Society, London: Macmillan.

Schnell, I, and Benjamini, Y. (2005). Globalisation and the Structure of Urban Social Space: The Lesson from Tel Aviv. Urban Studies 42(13):2489-2510.

Slater, T. (2006) The eviction of critical perspectives from gentrification discourse. International Journal of Urban and Regional Research 30.4, 737-57.

Smith N., P. Williams, 1986, Gentrification of the city, London, Allen \& Unwin. 
Speare, Alden Goldstein, Sidney and Frey, William.H. (1975). Residential mobility, migration, and metropolitan change. Cambridge, Mass: Ballinger

Speare, Alden (1974), Residential Satisfaction as an Intervening Variable in Residential Mobility. Demography 11(2), 173-188

Stillwell, John. and Duke-Williams, Oliver. (2005) Ethnic population distribution, immigration and internal migration in Britain. What evidence of linkage at the district scale, in BSPS (ed) British Society for Population Studies. Canterbury: University of Kent at Canterbury.

Wahlstrom Andrew, K. (2005). Liberal Democracies and Encompassing Religious Communities: A Defense of Autonomy and Accommodation, Journal of Social Philosophy, 36 (1), 31-48.

Waterman, Stanley and Kosmin, Barry. A. (1987). Residential change in a middle-class suburban ethnic population: a comment, Transactions of the Institute of British Geographers (N.S.) 12 (1), 107-112.

Waterman, S. and Kosmin, B. (1988). Residential patterns and processes: a study of Jews in three London boroughs. Transactions of the Institute of British Geographers 13, 79-95.

White, P. (1984) The West-European city. A social geography. Longman, London.

Zhang, Tonglin and Linb, Ge (2007). A decomposition of Moran's I for clustering detection. Computational Statistics and Data Analysis, (51), 6123-6137. 


\section{Residential choices as a driving force to vertical segregation in Whitechapel}
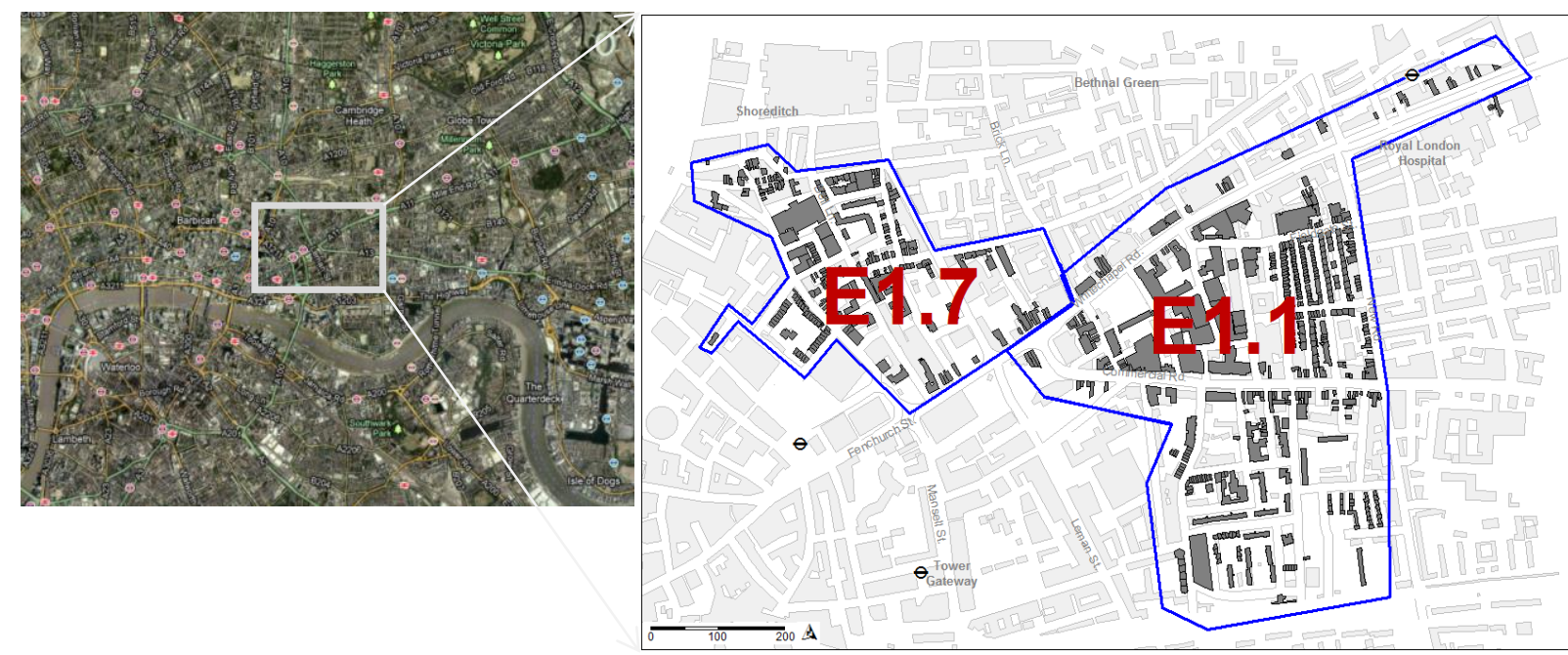

Figure 1: (a) the research area within its surroundings (b) Postcode areas E1.1 and E1.7.

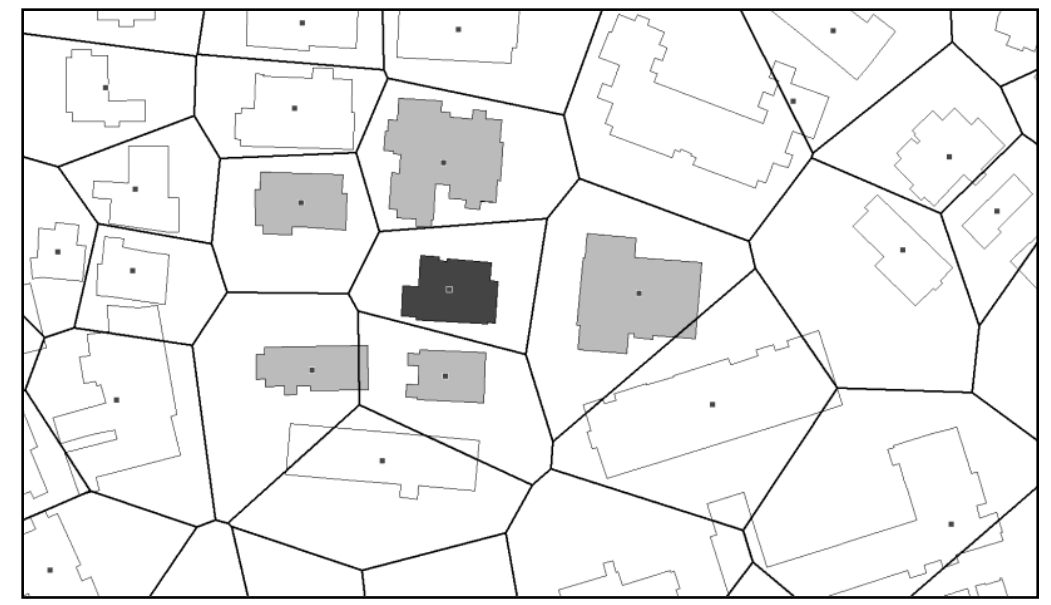

Figure 2: Whitechapel buildings and the coverage of Voronoi polygons constructed based of buildings' centroids. Voronoi-neighbours of the selected building (Black) are shown in Gray. 


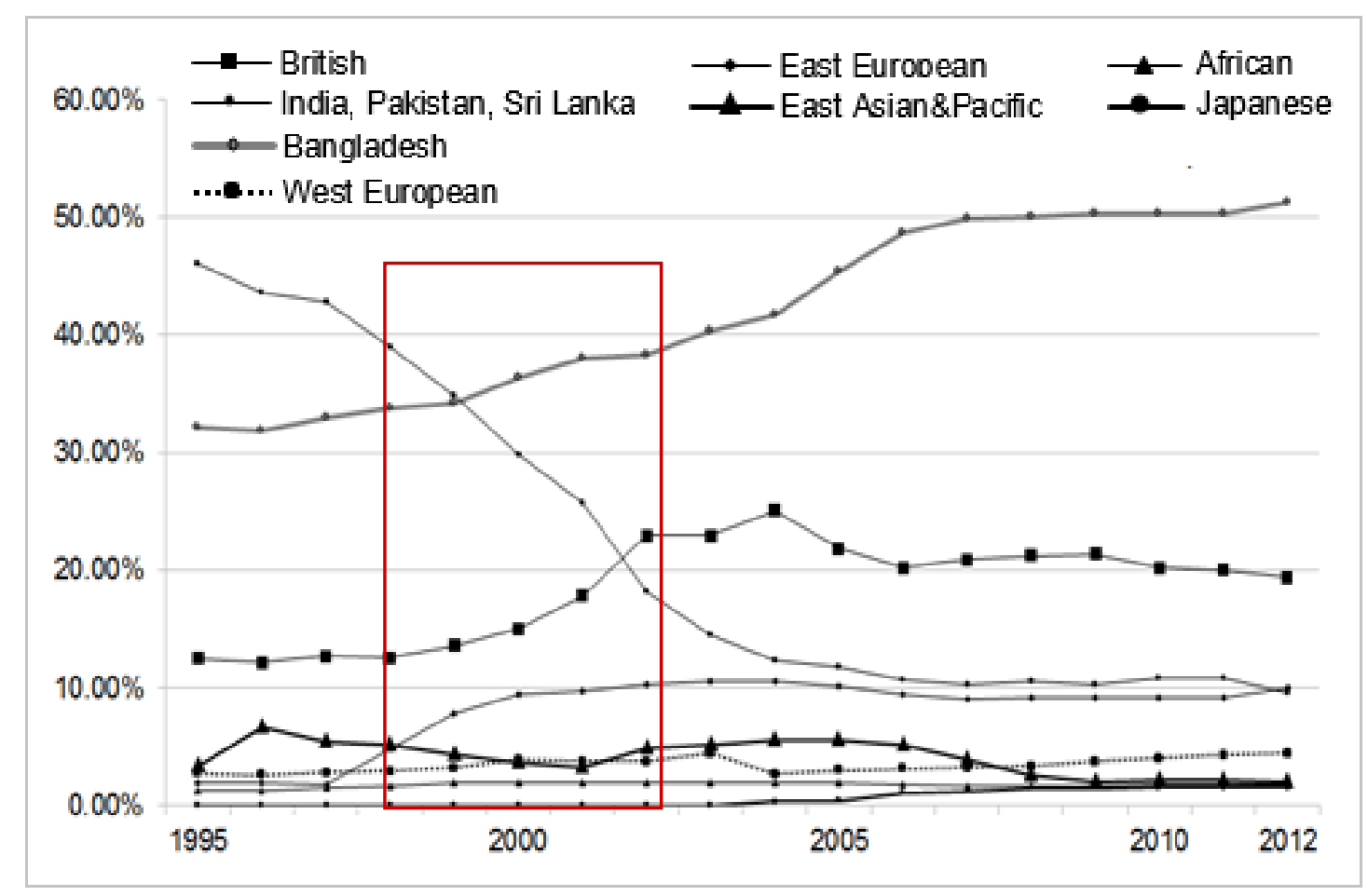

Figure 3: Population dynamics in the research area of Whitechapel: (percentages).
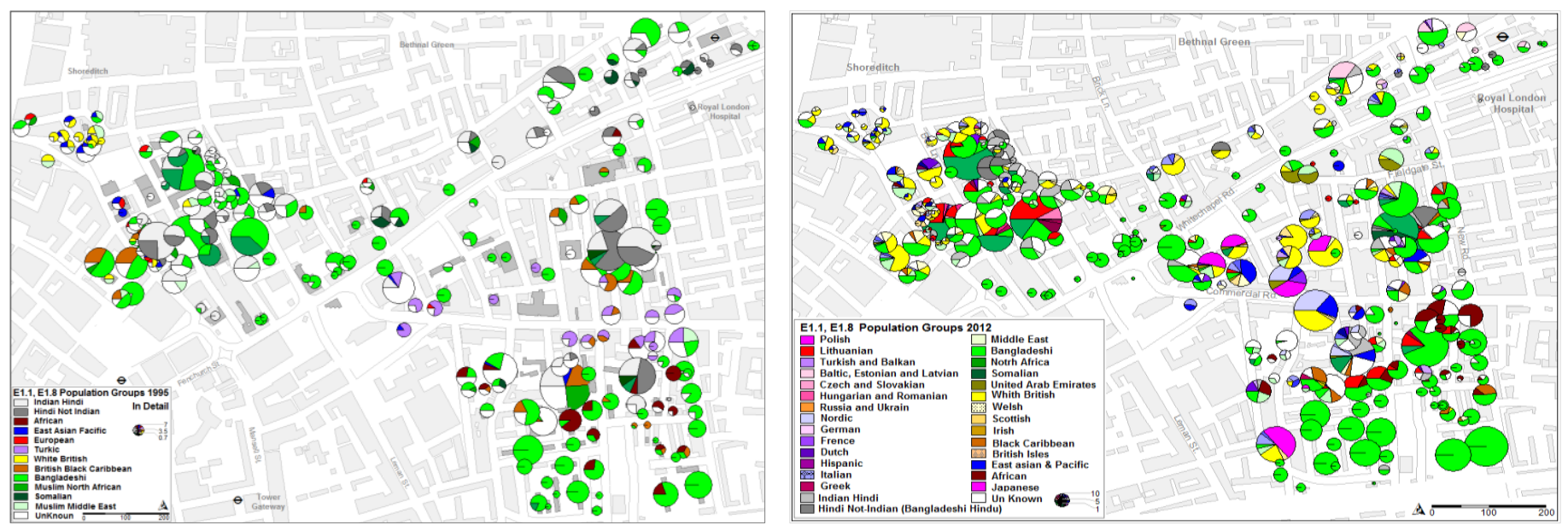

Figure 4: Spatial distribution of various population groups in apartment buildings, Whitechapel $1995-2012$. 


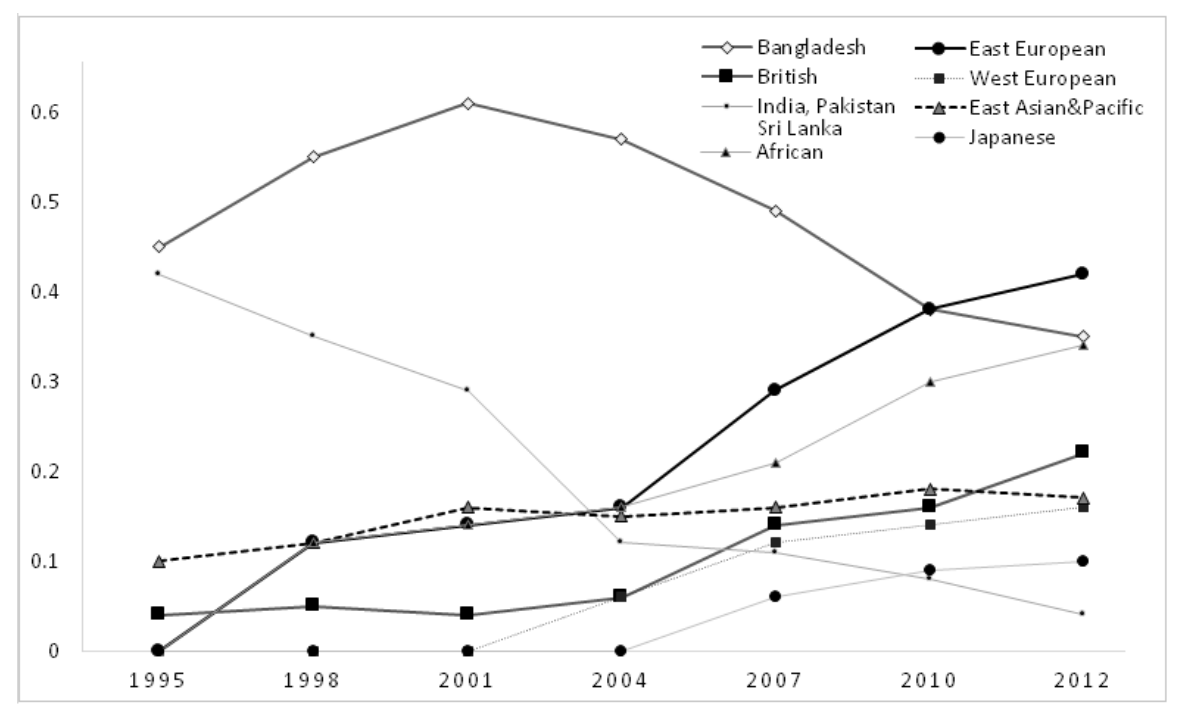

Figure 5: The dynamics of groups' residential segregation in Whitechapel, according to Moran I index, during the period of 1995 - 2012

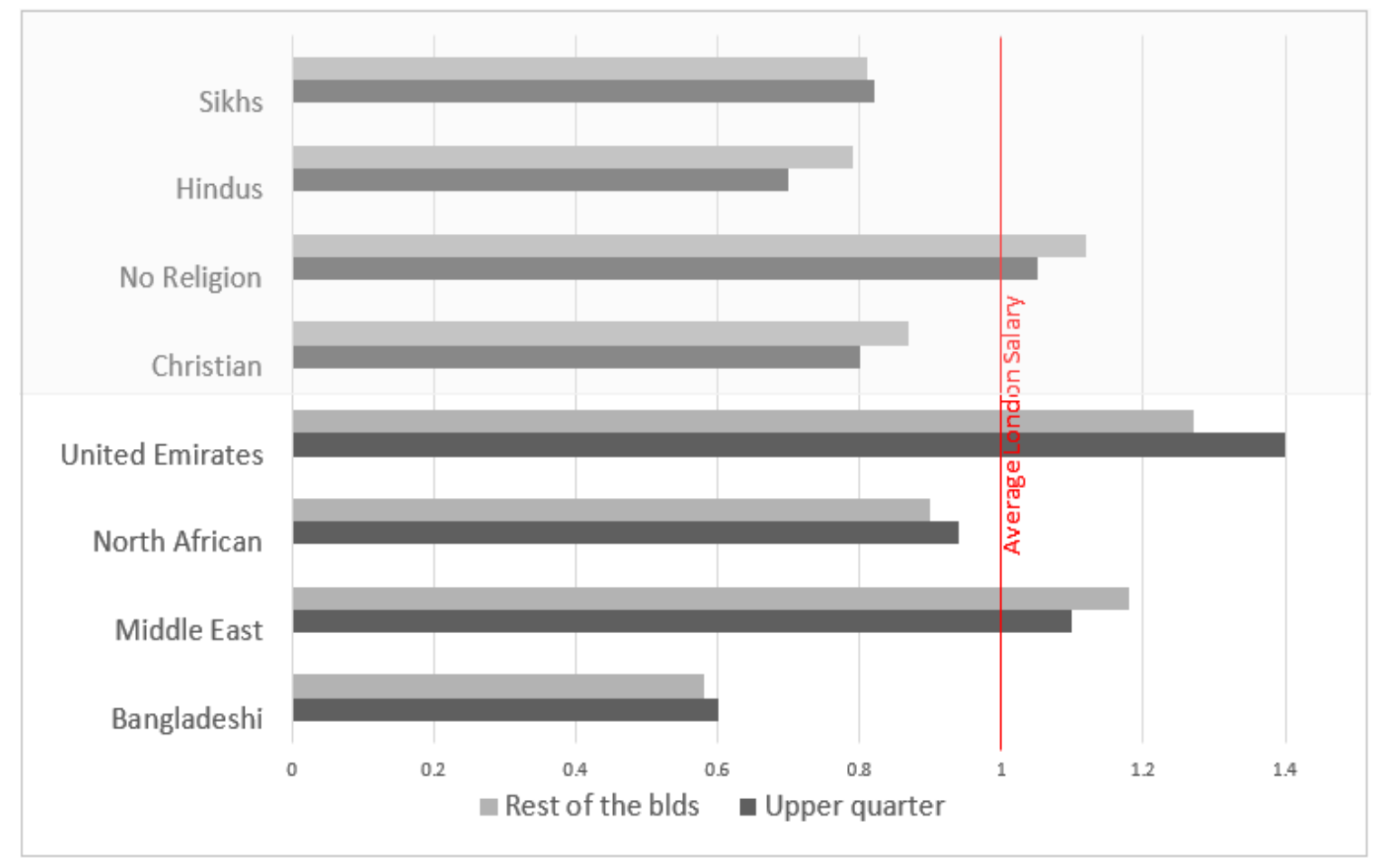

Figure 6: Stated average income (including family support) by group and location of the flat in the buildings 2012. Top: by faith, Bottom: by Muslims sub-groups. Source for the Average London Salary: Labour Force Survey, ONS 2012 
India,

East-

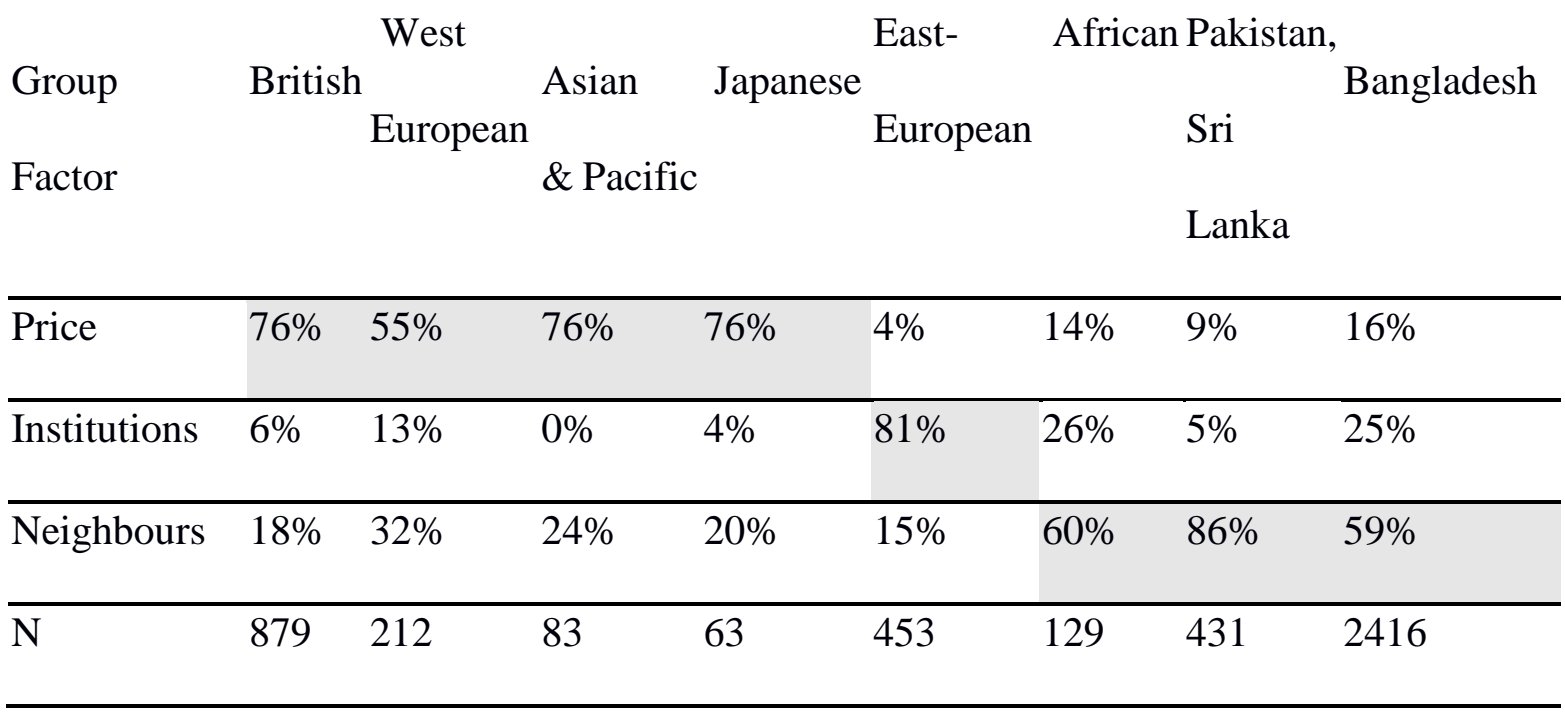

Table 1: Importance of flat cost, neighbours' identity and proximity to institutions in flat choice by population group, Whitechapel (2015)

Living in the...

\begin{tabular}{lll}
\hline upper quarter bottom quarter \\
\hline $\mathrm{N} \quad$ of the flats $\mathrm{N} \quad$ of the flats
\end{tabular}

\begin{tabular}{lcccc}
\hline Muslims & 1629 & $80.5 \%$ & 84 & $3.5 \%$ \\
\hline Christians (Inc. CofE, Catholic, Protestant & & 91 & $24.8 \%$ \\
and other denominations) & 108 & $10.2 \%$ & & \\
& & & & \\
\hline No Religion & 28 & $2.5 \%$ & 86 & $22.8 \%$ \\
\hline Hindus & 24 & $2.2 \%$ & 178 & $48.7 \%$ \\
\hline Sikhs & 51 & $4.1 \%$ & 0 & 0 \\
\hline
\end{tabular}

Table 2: Distribution of families in buildings by faith 


\begin{tabular}{lllllll}
\hline \hline & \multicolumn{3}{l}{ Living in the ... } \\
\cline { 2 - 7 } & $\mathrm{N}$ Upper quarter & \multicolumn{4}{l}{ Bottom quarter } \\
\cline { 2 - 7 } & $\mathrm{N}$ & & $\begin{array}{l}\text { of the flats of the total } \mathrm{N} \\
\text { pop. group }\end{array}$ & $\begin{array}{l}\text { of } \\
\text { flats }\end{array}$ & $\begin{array}{c}\text { the of the total pop. } \\
\text { group }\end{array}$ \\
\hline Bangladeshi & 1268 & $67.6 \%$ & $52.5 \%$ & 79 & $3.2 \%$ & $3.2 \%$ \\
\hline Middle East & 22 & $5.5 \%$ & $75.8 \%$ & 5 & $0.3 \%$ & $17.1 \%$ \\
\hline North African & 19 & $1.8 \%$ & $55.8 \%$ & 0 & 0 & 0 \\
\hline $\begin{array}{l}\text { United Arab } \\
\text { Emirates }\end{array}$ & 59 & $5.6 \%$ & $89.3 \%$ & 0 & 0 & 0 \\
\hline
\end{tabular}

Table 3: Distribution of families in buildings by Muslim groups

\begin{tabular}{|c|c|c|c|c|}
\hline & Bangladesh & $\begin{array}{l}\text { East- } \\
\text { European }\end{array}$ & $\begin{array}{l}\text { India, } \\
\text { Pakistan, } \\
\text { Sri Lanka }\end{array}$ & British \\
\hline $\begin{array}{l}\text { Population percentage of a group } \\
\text { Significance of the K-S criterion }\end{array}$ & $\begin{array}{l}51.8 \% \\
p=0.012\end{array}$ & $\begin{array}{l}10.5 \% \\
p=0.000\end{array}$ & $\begin{array}{l}10 \% \\
p=0.002\end{array}$ & $\begin{array}{l}19 \% \\
p=0.78\end{array}$ \\
\hline $\begin{array}{l}\text { Percentage of buildings without } \\
D \text {, based on binomial distribution }\end{array}$ & $0.4 \%$ & $31.4 \%$ & $32.1 \%$ & $14.1 \%$ \\
\hline $\begin{array}{l}\text { Percentage of buildings without } \\
\text { D, real }\end{array}$ & $7.8 \%$ & $44.6 \%$ & $39.7 \%$ & $15.9 \%$ \\
\hline $\begin{array}{l}\text { D-percentage in populated } \\
\text { buildings, based on binomial } \\
\text { distribution }\end{array}$ & $25.3 \%$ & $23.6 \%$ & $21.4 \%$ & $21.1 \%$ \\
\hline $\begin{array}{l}\text { D-percentage in populated } \\
\text { buildings, real }\end{array}$ & $32.4 \%$ & $31.1 \%$ & $23.2 \%$ & $21.8 \%$ \\
\hline
\end{tabular}

Table 4: Group' segregation in the buildings, 2012; note that total population percentage of four population groups in Whitechapel is 91 . 


\begin{tabular}{lllll}
\hline \hline Period & Bangladesh & East- & India, & British \\
& & European & Pakistan, & \\
& & & Sri Lanka & \\
& & & & \\
& & & 0.46 & 0.74 \\
\hline $1995-2012$ & 0.99 & 0.49 & & \\
\hline
\end{tabular}

Table 5: Averaged over 1995-2012 probability to replace a family of an own group

\begin{tabular}{lllll}
\hline \hline Upper quarter of buildings & Bangladeshi & Middle & North & United Arab \\
& & East & African & Emirates \\
& & & & \\
\hline Population percentage of a group & $27.2 \%$ & $0.5 \%$ & $0.4 \%$ & $1.2 \%$ \\
level of density (families per flat) & 4.6 & 0.9 & 2.6 & 2.6 \\
upper & & & & \\
\hline
\end{tabular}

Table 6: Level of density in the Upper quarter of buildings for certain population groups 